\title{
Antidiarrhoeal, antisecretory and antispasmodic activities of Matricaria chamomilla are mediated predominantly through $\mathrm{K}^{+}$-channels activation
}

\author{
Malik Hassan Mehmood ${ }^{1 *}$, Siraj Munir ${ }^{1 \dagger}$, Uzair Ali Khalid ${ }^{1 \dagger}$, Mudassir Asrar ${ }^{2+}$ and Anwarul Hassan Gilani ${ }^{1 \dagger}$
}

\begin{abstract}
Background: Matricaria chamomilla commonly known as "Chamomile" (Asteraceae) is a popular medicinal herb widely used in indigenous system of medicine for a variety of ailments. However, there is no detailed study available showing its effectiveness in hyperactive gut disorders like, abdominal colic and diarrhoea. This study was designed to determine the pharmacological basis for the folkloric use of Matricaria chamomilla in diarrhoea.

Methods: The crude aqueous-methanolic extract of Matricaria chamomilla (Mc.Cr) was studied for its protective effect in mice against castor oil-induced diarrhoea and intestinal fluid accumulation. The isolated rabbit jejunum was selected for the in-vitro experiments using tissue bath assembly coupled with PowerLab data acquisition system.

Results: Oral administration of Mc.Cr to mice at 150 and $300 \mathrm{mg} / \mathrm{kg}$ showed marked antidiarrhoeal and antisecretory effects against castor oil-induced diarrhoea and intestinal fluid accumulation, simultaneously, similar to the effects of cromakalim and loperamide. These effects of plant extract were attenuated in animals pretreated with $\mathrm{K}^{+}$channel antagonist, glibenclamide (GB) or 4-aminopyridine (4-AP). When tested in isolated rabbit jejunum, Mc.Cr caused a dosedependent $(0.3-3 \mathrm{mg} / \mathrm{ml})$ relaxation of spontaneous and low $\mathrm{K}^{+}(25 \mathrm{mM})$-induced contractions, while it exhibited weak inhibitory effect on high $\mathrm{K}^{+}(80 \mathrm{mM})$. The inhibitory effect of $\mathrm{Mc} . \mathrm{Cr}$ on low $\mathrm{K}^{+}$-induced contractions was partially inhibited in the presence of GB, while completely blocked by 4-AP. Cromakalim, an ATP-sensitive $\mathrm{K}^{+}$ channel opener, caused complete relaxation of low $\mathrm{K}^{+}$-induced contractions with little effect on high $\mathrm{K}^{+}$. Pretreatment of tissues with GB blocked the inhibitory effects of cromakalim on low $\mathrm{K}^{+}$, while the presence of 4-AP did not alter the original effect. Verapamil, a $\mathrm{Ca}^{++}$channel antagonist, caused complete relaxation of both low and high $\mathrm{K}^{+}$-induced contractions with similar potency. The inhibitory effect of verapamil was insensitive to GB or 4-AP. When assessed for $\mathrm{Ca}^{++}$antagonist like activity, $\mathrm{Mc} . \mathrm{Cr}$ at high concentrations caused rightward shift in the $\mathrm{Ca}^{++}$concentration-response curves with suppression of the maximum response, similar to the effect of verapamil, while cromakalim did not show similar effect.
\end{abstract}

Conclusions: This study indicates that Matricaria chamomilla possesses antidiarrhoeal, antisecretory and antispasmodic activities mediated predominantly through $\mathrm{K}^{+}$-channels activation along with weak $\mathrm{Ca}^{++}$ antagonist effect.

Keywords: Chamomile, Antidiarrhoeal, Antisecretory, Antispasmodic, $\mathrm{K}^{+}$channels activation, $\mathrm{Ca}^{++}$antagonist

\footnotetext{
* Correspondence: hassan.mehmood@aku.edu

${ }^{\dagger}$ Equal contributors

'Natural Product Research Division, Department of Biological and Biomedical

Sciences, Faculty of Health Sciences, Medical College, The Aga Khan

University, Stadium Road, P.O. Box 3500, Karachi 74800, Pakistan

Full list of author information is available at the end of the article
} 


\section{Background}

Matricaria chamomilla L. (synonym: Matricaria recutita) commonly known as Chamomile or German Chamomile, belongs to family Asteraceae [1]. Multiple species of Chamomile are spread over Europe, North-west Asia, North America, North Africa and the temperate regions of Asia [2,3]. In Pakistan, it is known as babuna or piunphulli and grows naturally in highlands of Balochistan such as, Hanna valley, Maslakh range, Muslimbagh, Kalat, Nushki, Kharan, Chaman and Ziarat. This plant is widely recognized and is more popular in the western culture for its diverse medicinal uses $[1,4]$. Since ancient times and in accordance with the references written by Hippocrates, Galen and Asclepius, its different parts including flowers, roots and oil have been used to treat variety of ailments [5].

Chamomile as a whole plant has been used traditionally in different forms for the treatment of multiple medical complaints such as, common cold, bronchitis, gastrointestinal spasms, epilepsy, hypertension, neuralgia, toothache, dysmenorrhea, eczema, impetigo, indigestion, colic and diarrhea [1,4-9]. Its flowers are also used as carminative and antipyretic, while its oil has been used in rheumatism, flatulence and colic [10]. In addition, this plant had a very long history of its medicinal use in ancient Egypt, Greece and Rome [11]. Chamomile is also one of the effective ingredients of several traditional formulations in the Unani and Homeopathy systems of medicine [11-15].

Phytochemical studies revealed the presence of alphabisabolol, cis-spiroethers sesquiterpenes (anthecotulid), cadinene, farnesene, furfural, spathulenol, and proazulene (matricarin and matricin) as plant constituents $[5,16]$. In addition, Chamomile has also been found to possess around $8 \%$ of flavone glycosides (apigenin 7-glycoside and its 6'-acetylated derivative) and flavonols (luteolin glucosides, quercetin glycosides, and isohamnetin); $10 \%$ of mucilage polysaccharides; $0.3 \%$ of choline and $0.1 \%$ of coumarins (umbelliferone and its methyl ether, herniarin). The presence of tannin in chamomile has also been detected less than 1\% [17-19].

Pharmacological investigations showed that Matricaria chamomilla possesses antiinflammatory [20], antispasmodic [21,22], antibacterial [23], digestive [24], antioxidant and antidiabetic [25,26] activities. However, there is little evidence available to its medicinal use in diarrhoea. This study has been planned to explore the scientific basis for the medicinal use of Matricaria chamomilla in hyperactive gut disorders, like diarrhoea and abdominal spasms using different in vivo and in vitro assays.

\section{Methods}

\section{Plant material and extraction}

The aerial parts of Matricaria chamomillla L. collected and identified by Dr. Mudassir Asrar (University of Balochistan, Quetta, Pakistan). A voucher specimen \# BGUOB-187 was deposited in the herbarium of Department Botany, University of Balochistan. The dried plant material weighing $400 \mathrm{~g}$ was used for extraction and soaked in 70\% methanol for three days, with occasional shaking. The soaked material was filtered through a muslin cloth and then through a Whatman qualitative grade 1 filter paper. This procedure was repeated three times and the combined filtrate was evaporated using rotary evaporator to get the final aqueous-methanolic extract of Matricaria chamomillla (Mc. Cr), yielding 15\% w/w [27].

\section{Drugs and animals}

Potassium chloride, verapamil hydrochloride, loperamide and 4-aminopyridine were purchased from Sigma Chemicals Co, St Louis, MO, USA. Cromakalim and glibenclamide were purchased from Tocris, Ellisville, $\mathrm{MO}$ and RBI Chemicals Co, Natick, MA, USA respectively. Castor oil was purchased from Karachi chemical industries (Pvt.) Ltd. F/25 S. I. T. E., Karachi (Pakistan). All chemicals used were of the analytical grade available and solubilized in distill water/saline except cromakalim and glibenclamide, which were dissolved in $10 \%$ DMSO to prepare stock solutions. The vehicle used for solubilization was found inert on isolated tissue preparations in control experiments. Stock solutions of all chemicals were made fresh in normal saline on the day of the experiment.

BALB/c mice (weighing 20-25 g) and locally bred rabbits (weighing 1-1.5 kg) of both genders, were housed at the Animal House of Aga Khan University under controlled environmental conditions $\left(23-25^{\circ} \mathrm{C}\right)$. The animals were fasted for $12-16 \mathrm{~h}$ before the experiment, whereas they were given tap water and standard diet routinely. Experiments were performed with the rulings of the Institute of Laboratory Animal Resources, Commission on Life Sciences, National Research Council [28] and also in accordance with Institutional guidelines. The study protocol (016-ECACU-BBS-13) was approved by the Ethics Committee for Animal Care and Use (ECACU) of the Aga Khan University.

\section{In-vivo assays \\ Antidiarrhoeal activity}

Mice (20-25 g, $\mathrm{n}=78$ ) of either gender were fasted for $12-16 \mathrm{~h}$ before the experiment. The animals were housed in individual cages and divided into 13 groups, each containing six animals. The first group received saline along with solubilizing vehicle $(10 \mathrm{ml} / \mathrm{kg})$ orally (p.o.), acted as negative control. The group 2 and 3 received cromakalim (10 mg/kg, p.o.) and loperamide (10 mg/kg, p.o.), respectively, serving as the positive controls. The group 4 and 5 received different doses (150 and $300 \mathrm{mg} / \mathrm{kg}$, p.o.) of Mc. Cr. Of the remaining eight groups, the group $6,8,10$ and 12 were pretreated with glibenclamide (GB, $3 \mathrm{mg} / \mathrm{kg}$, i.p.) and the group 7, 9, 11 and 13 were 
administered 4-aminopyridine (4-AP, $5 \mathrm{mg} / \mathrm{kg}$, i.p.) $30 \mathrm{~min}$ before re-administration of cromakalim, loperamide or Mc. Cr. After $1 \mathrm{~h}$ of respective treatments, each animal received $10 \mathrm{ml} / \mathrm{kg}$ castor oil orally through a feeding needle. After $5 \mathrm{~h}$, the mouse cages were individually inspected for mean defecation per group, mean number of wet feces and mean number of dry feces. The percentage protection in each group was calculated as, (mean number of dry feces/mean defecation) $\times 100$ [29].

\section{Intestinal fluid accumulation}

By following previously described method with slight modification [30], 12-16 $\mathrm{h}$ fasted mice (weighing 20-25 g, $\mathrm{n}=84$ ) of either gender were housed in cages in fourteen equally divided groups $(n=6)$. The first two groups received saline in a solubilizing vehicle $(10 \mathrm{ml} / \mathrm{kg}$, p.o.) and acted as negative controls. The animals in group 3 and 4 were administered cromakalim $(10 \mathrm{mg} / \mathrm{kg})$ and loperamide $(10 \mathrm{mg} / \mathrm{kg})$ intraperitoneally (i.p.), respectively, using a detachable U-100 insulin syringe with a $25 \mathrm{G} \times 1$ " $(0.50 \times 25 \mathrm{~mm})$ needle, as the positive controls. The group 5 and 6 were treated with increasing doses of the plant extract (150 and $300 \mathrm{mg} / \mathrm{kg}$, p.o.). The group 7, 9, 11 and 13 were pretreated with glibenclamide (GB, $3 \mathrm{mg} / \mathrm{kg}$, i.p.), while the group $8,10,12$ and 14 were pretreated 4-aminopyridine (4-AP, $5 \mathrm{mg} / \mathrm{kg}$, i.p.) $30 \mathrm{~min}$ before re-administration of cromakalim, loperamide or Mc. Cr. After $1 \mathrm{~h}$ of the respective treatments, each animal received castor oil (10 ml/kg. p.o.), except the animals in group one. All the animals were sacrificed 30 min later by cervical dislocation and the intestine was dissected out carefully, not allowing any intestinal fluid to leak out, and weighed. The results were expressed as $(\mathrm{Pi} / \mathrm{Pm}) \times 1000$ whereas, $P i$ is the weight of the intestine and $P m$ is the weight (in g) of the animal.

\section{Acute toxicity test}

A total of $40 \mathrm{Balb} / \mathrm{c}$ mice (20-25 g) of either sex were equally divided into four groups. The test was performed using increasing doses of the crude extract of the Matricaria chamomillla ( 1,3 and $5 \mathrm{~g} / \mathrm{kg}$ ) given orally in $10 \mathrm{ml} / \mathrm{kg}$ control vehicle to different animals serving as the test groups. Another group of mice was administered control vehicle $(10 \mathrm{ml} / \mathrm{kg})$ orally as the negative control. The animals were allowed food and water ad libitum and kept under regular observation for $6 \mathrm{~h}$ to observe their piloerection, changes in exploratory behavior and blindness, while lethality was monitored up to $24 \mathrm{~h}$.

\section{In-vitro experiments}

\section{Antispasmodic activity}

The spasmolytic activity of the test material was studied by using isolated rabbit jejunum preparations [31]. Respective segments of $2 \mathrm{~cm}$ in length were suspended individually in $10 \mathrm{ml}$ tissue baths containing Tyrode's solution, aerated with a mixture of $95 \%$ oxygen and $5 \%$ carbon dioxide (carbogen) and maintained at $37^{\circ} \mathrm{C}$ using thermo-circulator. The composition of the Tyrode's solution in $\mathrm{mM}$ was: $\mathrm{KCl} 2.68, \mathrm{NaCl} 136.9, \mathrm{MgCl}_{2} 1.05$, $\mathrm{NaHCO}_{3}$ 11.90, $\mathrm{NaH}_{2} \mathrm{PO}_{4} \quad 0.42, \mathrm{CaCl}_{2} 1.8$ and glucose 5.55 (pH 7.4). Intestinal responses were recorded isotonically using Bioscience Transducers coupled with PowerLab data acquisition system (ADInstruments, Sydney, Australia). Each tissue was allowed to equilibrate for at least $30 \mathrm{~min}$ before the addition of any drug and then stabilized with a sub-maximal concentration of acetylcholine (ACh, $0.3 \mu \mathrm{M}$ ) and the bath fluid was subsequently replaced with normal Tyrode's solution before starting the experiment.

The myorelaxant effect of the plant extract was assessed on spontaneously contracting isolated rabbit jejunum. For elucidation of the possible mechanism of spasmolytic effect, low $\mathrm{K}^{+}(25 \mathrm{mM})$ and high $\mathrm{K}^{+}(80 \mathrm{mM})$ were used to depolarize the isolated tissues which in turn produced sustained contractions, which are considered useful for determining the different inhibitory mechanisms like, $\mathrm{K}^{+}$ channel activation [32] and $\mathrm{Ca}^{++}$channel blockade [33], respectively. The test material was then added in a cumulative fashion to obtain concentration-dependent inhibitory responses. The relaxation of isolated tissue preparations was expressed as percent of the control response mediated by added low or high $\mathrm{K}^{+}$-induced concentrations.

To know the nature of $\mathrm{K}^{+}$channels involved in the inhibitory effect of the test material, the spasmolytic effect of the test material was studied on low $\mathrm{K}^{+}$-induced contractions in the absence and presence of glibenclamide (GB), an ATP-dependent $\mathrm{K}^{+}$-channel blocker [34] or 4aminopyridine (4-AP), a voltage-dependent $\mathrm{K}^{+}$channel blocker [35].

To confirm the presence of $\mathrm{Ca}^{++}$antagonist like activity in the test material, the tissue were allowed to stabilize in normal Tyrode's solution, which was then replaced with $\mathrm{Ca}^{++}$-free Tyrode's solution containing EDTA $(0.1 \mathrm{mM})$ for $30 \mathrm{~min}$ in order to chelate $\mathrm{Ca}^{++}$from the environment and the tissues [36]. This solution was further replaced with $\mathrm{K}^{+}$-rich and $\mathrm{Ca}^{++}$-free Tyrode's solution with following constitution $(\mathrm{mM}): \mathrm{KCl} 50, \mathrm{NaCl} 91.04, \mathrm{MgCl}_{2} 1.05$, $\mathrm{NaHCO}_{3}$ 11.90, $\mathrm{NaH}_{2} \mathrm{PO}_{4}$ 0.42, glucose 5.55 and EDTA 0.1 . After an incubation period of $30 \mathrm{~min}$ in normal Tyrode's solution, the concentration-response curves (CRCs) of $\mathrm{Ca}^{++}$were constructed. When the control CRCs of $\mathrm{Ca}^{++}$were found super imposable (usually after two cycles), then the tissue was pre-incubated with test substance for 60 min to confirm the possible $\mathrm{Ca}^{++}$antagonist like activity [37]. In the presence of different concentrations of the test material, the CRCs of $\mathrm{Ca}^{++}$were reconstructed. Non-parallel rightward shift with suppression of the maximum response of $\mathrm{Ca}^{++}$in the presence of 
test substance indicates $\mathrm{Ca}^{++}$antagonist-like antispasmodic activity.

\section{Statistical analysis}

All the data expressed are mean \pm standard error of mean (s.e.m., $\mathrm{n}=$ number of experiments) and the median effective concentrations $\left(\mathrm{EC}_{50}\right.$ values) with $95 \%$ confidence intervals (CI). The concentration-response curves were analyzed by non-linear regression (Graph-PAD program, Graph-PAD, San Diego, CA, USA). Unpaired $t$-test or One-way ANOVA followed by Dunnett's test was used for antidiarrhoeal and intestinal fluid accumulation assays. Probability of less than 0.05 was considered significantly different.

\section{Results}

\section{Effect of Matricaria chamomillla on castor oil-induced} diarrhoea in mice

Oral administration of Matricaria chamomillla exhibited dose-dependent inhibitory effect against castor oil-induced diarrhoea in mice by producing 41.4 and $61.9 \%$ protection at the respective doses of 150 and $300 \mathrm{mg} / \mathrm{kg}$. The positive controls of cromakalim and loperamide caused 65.2 and $77.2 \%$ protection, respectively, while saline treated group showed only $12.4 \%$ protection. When the effect of Mc. $\mathrm{Cr}$ was restudied in mice pretreated with GB or 4-AP, it was attenuated to 34.1 and $22.5 \%$ vs. $41.4 \%$ (effect of Mc. Cr without antagonist), respectively, at $150 \mathrm{mg} / \mathrm{kg}$, and decreased to 44.9 and $29.8 \%$ vs. $61.9 \%$ at $300 \mathrm{mg} / \mathrm{kg}$.
Similarly, the effect of cromakalim was significantly reduced to $25.6 \%$ vs. $65.2 \%$ when reproduced in the presence of GB, while remained devoid of any significant change in the presence of 4-AP. Loperamide did not show sensitivity to GB or 4-AP (Table 1).

Further to assess its inhibitory effect on intestinal secretions, Mc. Cr was studied on castor oil-induced intestinal fluid accumulation in mice.

\section{Effect of Matricaria chamomillla on castor oil-induced intestinal fluid accumulation in mice}

In enteropooling assay, castor oil administration caused a substantial increase $(p<0.001)$ of fluid accumulation in mice with $(\mathrm{Pi} / \mathrm{Pm}) \times 1,000$ value of $150 \pm 8.0$ when compared with saline administered group (105 \pm 4.5$)$. The administration of Mc. Cr to mice produced a significant $(p<0.001)$ reduction in castor oil-induced fluid accumulation at 150 and $300 \mathrm{mg} / \mathrm{kg}$ with respective $(\mathrm{Pi} / \mathrm{Pm}) \times$ 1,000 values of $96 \pm 4.6$ and $90 \pm 1.2$, similar to the effects cromakalim $(84 \pm 2.7)$ and loperamide $(75 \pm 3.2)$ at the doses of $10 \mathrm{mg} / \mathrm{kg}$, respectively. When the inhibitory potential of Mc. $\mathrm{Cr}$ on castor oil-induced fluid accumulation was restudied in mice pretreated with GB or 4-AP, it was attenuated with resultant values of $105 \pm 2.4$ and $112 \pm 4.9$ vs. $96 \pm 4.6$ (effect of Mc. Cr without antagonist), respectively at $150 \mathrm{mg} / \mathrm{kg}$, and also decreased with respective values of $108 \pm 1.5$ and $119 \pm 1.2$ vs. $90 \pm 1.2$ at $300 \mathrm{mg} / \mathrm{kg}$. Similarly, the effect of cromakalim was significantly reduced in the presence of GB with resultant value of $135 \pm$

Table 1 Antidiarrhoeal effect of the crude extract of Matricaria chamomilla (Mc.Cr) against castor oil (10 mL/kg)-induced diarrhoea in mice without and with pre-administration of $3 \mathrm{mg} / \mathrm{kg}$ glibenclamide (GB) or $5 \mathrm{mg} / \mathrm{kg}$ 4-aminopyridine (4-AP)

\begin{tabular}{|c|c|c|c|c|c|c|}
\hline Group no. & Treatment & Dose (mg/kg) & Mean defecation/group & $\begin{array}{l}\text { Mean no. of wet } \\
\text { feces/group }\end{array}$ & $\begin{array}{l}\text { Mean no. of dry } \\
\text { feces/group }\end{array}$ & $\%$ Protection \\
\hline 1 & Castor oil $(10 \mathrm{~mL} / \mathrm{kg})+$ Saline & 10 & $8.92 \pm 1.24$ & $7.81 \pm 2.11$ & $1.11 \pm 0.21$ & $12.4 \%$ \\
\hline 2 & Castor oil + Cromakalim & 10 & $6.67 \pm 0.90^{\#}$ & $2.32 \pm 0.40^{\# \# \#}$ & $4.35 \pm 1.70^{\#}$ & $65.2 \%$ \\
\hline 3 & Castor oil + Loperamide & 10 & $4.70 \pm 0.90^{\# \# \#}$ & $1.07 \pm 0.30^{\# \# \#}$ & $3.63 \pm 0.90^{\#}$ & $77.2 \%$ \\
\hline 4 & Castor oil + Mc.Cr (p.o) & 150 & $5.47 \pm 1.37^{* *}$ & $3.20 \pm 0.50^{* *}$ & $2.27 \pm 0.58^{*}$ & $41.4 \%$ \\
\hline 5 & Castor oil + Mc.Cr (p.o.) & 300 & $4.20 \pm 0.29^{* * *}$ & $1.61 \pm 0.92^{* * *}$ & $2.59 \pm 0.33^{*}$ & $61.7 \%$ \\
\hline \multicolumn{7}{|c|}{ Effect of different treatments in the presence of GB or 4-AP } \\
\hline 6 & Castor oil + GB + Cromakalim & $3+10$ & $7.40 \pm 0.95^{\$}$ & $5.50 \pm 0.70^{\$ \$ \$}$ & $1.90 \pm 0.85^{\$ \$}$ & $25.6 \%$ \\
\hline 7 & Castor oil + 4-AP + Cromakalim & $5+10$ & $6.70 \pm 0.50$ & $2.80 \pm 0.75$ & $3.90 \pm 0.35^{\$}$ & $58.2 \%$ \\
\hline 8 & Castor oil + GB + Loperamide & $3+10$ & $4.90 \pm 0.39$ & $1.40 \pm 0.50$ & $3.50 \pm 0.90$ & $71.4 \%$ \\
\hline 9 & Castor oil + 4-AP + Loperamide & $5+10$ & $5 \pm 1.73$ & $1.31 \pm 0.90$ & $3.69 \pm 0.45$ & $73.8 \%$ \\
\hline 10 & Castor oil + GB + Mc.Cr & $3+150$ & $5.83 \pm 0.50$ & $3.84 \pm 0.37^{\$}$ & $1.99 \pm 0.36$ & $34.1 \%$ \\
\hline 11 & Castor oil + 4-AP + Mc.Cr & $5+150$ & $6.11 \pm 0.49^{\$}$ & $4.73 \pm 0.31^{\$ \$}$ & $1.38 \pm 0.41^{\$}$ & $22.5 \%$ \\
\hline 12 & Castor oil + GB + Mc.Cr & $3+300$ & $5.56 \pm 0.50^{\$}$ & $3.06 \pm 0.57^{\$ \$}$ & $2.50 \pm 0.62$ & $44.9 \%$ \\
\hline 13 & Castor oil + 4-AP + Mc.Cr & $5+300$ & $5.80 \pm 0.46^{\$ \$}$ & $4.07 \pm 0.57^{\$ \$ \$}$ & $1.73 \pm 0.70^{\$}$ & $29.8 \%$ \\
\hline
\end{tabular}

p.o. (per oral), Values shown are mean \pm S.E.M. of 6 determinations.

\# $<<0.05$ and \#\#\# $<0.001$ show a comparison of group \#2 and 3 with group \#1.

${ }^{*} p<0.05,{ }^{* *} p<0.01$ and ${ }^{* * *} p<0.001$ show a comparison of group \# 4 and 5 with group \#1.

$\$ p<0.05,{ }^{\$ \$} p<0.01$ and ${ }^{\$ \$} p<0.001$ show a comparison of group \# 6-13 with their respective treatments without GB or 4-AP (One-way ANOVA followed by Dunnet's test). 
1.8 vs. $84 \pm 2.7$, while it remained unaltered in the presence of 4-AP. However, loperamide did not show sensitivity to GB or 4 -AP (Figure 1$)$. All $(\mathrm{Pi} / \mathrm{Pm}) \times 1,000$ values are expressed as mean \pm s.e.m. $(n=6)$.

\section{Acute toxicity test}

The plant extract was well tolerated by the animals up to the tested oral dose of as high as $5 \mathrm{~g} / \mathrm{kg}$. No sign of acute toxicity like restlessness, seizures and piloerection
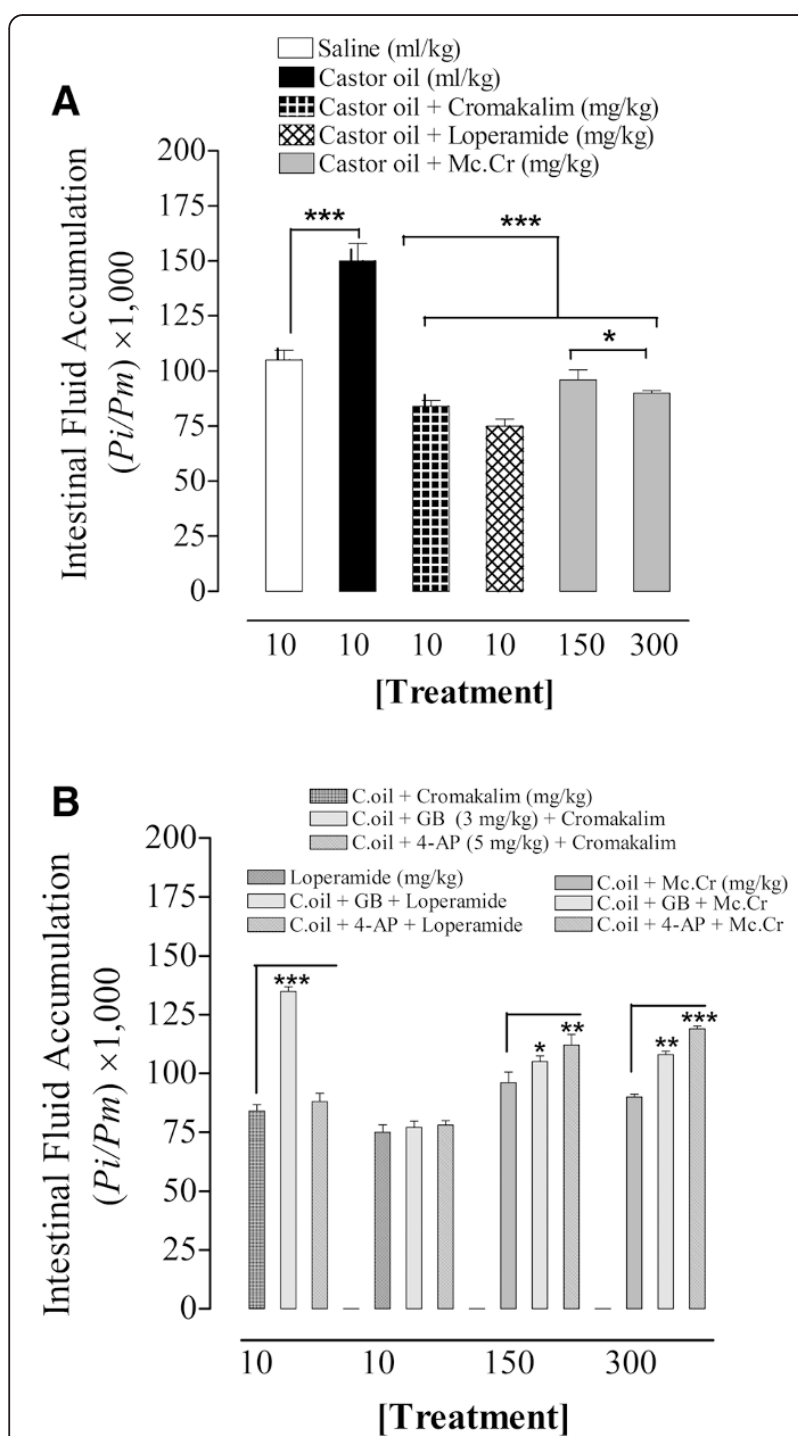

Figure 1 Antidiarrhoeal and antisecretory effects of Matricaria chamomilla in mice. The dose-dependent inhibitory effect of the crude extract of Matricaria chamomilla (Mc. Cr) on castor oil-induced fluid accumulation in the small intestine of mice, (A) without and (B) with glibenclamide (GB) or 4-aminopyridine (4-AP). Intestinal fluid accumulation is expressed as $P i / P m \times 1000$, whereas $P i$ is the weight of the small intestine and $P m$ is the weight (in g) of the mouse. The values are mean \pm s.e.m., $n=6 .{ }^{*} p<0.05,{ }^{* *} p<0.01$ and ${ }^{* *} p<0.001$ (Unpaired $t$-test or One-way ANOVA followed by Dunnett's test) was noticed over the period of observation $(6 \mathrm{~h})$ and there was no death recorded up to $24 \mathrm{~h}$.

In order to investigate the presence of gut relaxant constitutes in Mc. Cr, which might be mediating its antidiarrhoeal and antisecretory activities, isolated rabbit jejunum was selected for further studies.

\section{Effect of Matricaria chamomillla on Rabbit Jejunum}

The plant extract inhibited potently the spontaneous and low $\mathrm{K}^{+}$-induced contractions with respective $\mathrm{EC}_{50}$ values of $0.89 \mathrm{mg} / \mathrm{ml}(0.63-1.19,95 \% \mathrm{CI}, \mathrm{n}=5)$ and $0.77 \mathrm{mg} / \mathrm{ml}$ $(0.59-0.97, \mathrm{n}=7)$ compared to its effect $(2.80 \mathrm{mg} / \mathrm{ml}(1.79$ $3.21, \mathrm{n}=6)$ on high $\mathrm{K}^{+}$-induced contractions as shown in Figure 2. When its effect on low $\mathrm{K}^{+}$-induced contractions was restudied in the presence glibenclamide (GB), it was significantly inhibited with resultant $\mathrm{EC}_{50}$ value of $3.09 \mathrm{mg} / \mathrm{ml}(2.21-3.76, \mathrm{n}=4)$ vs. $0.77 \mathrm{mg} / \mathrm{ml}(0.59-0.97$, $\mathrm{n}=7$ ). In the presence 4-aminopyridine (4-AP), the relaxant effect of $\mathrm{Mc}$. $\mathrm{Cr}$ was almost blocked with remaining maximum relaxation of only $29.73 \pm 12.70 \%$ vs. $100 \%$ $(\mathrm{n}=4-5)$ at the highest tested concentration of $10 \mathrm{mg} / \mathrm{ml}$ (Figure 3A).

Cromakalim also caused complete relaxation of low $\mathrm{K}^{+}$with an $\mathrm{EC}_{50}$ value of $0.92 \mu \mathrm{M}(0.56-1.34, \mathrm{n}=5)$, while it had negligible effect on high $\mathrm{K}^{+}$-induced contractions, producing only $27.19 \pm 7 \%(\mathrm{n}=4)$ relaxation at the highest tested concentration of $10 \mu \mathrm{M}$. When its effect on low $\mathrm{K}^{+}$-induced contractions was studied in tissues pretreated with GB, it was significantly inhibited with remaining maximum relaxation of only $20.66 \pm 4.29 \%$ vs.

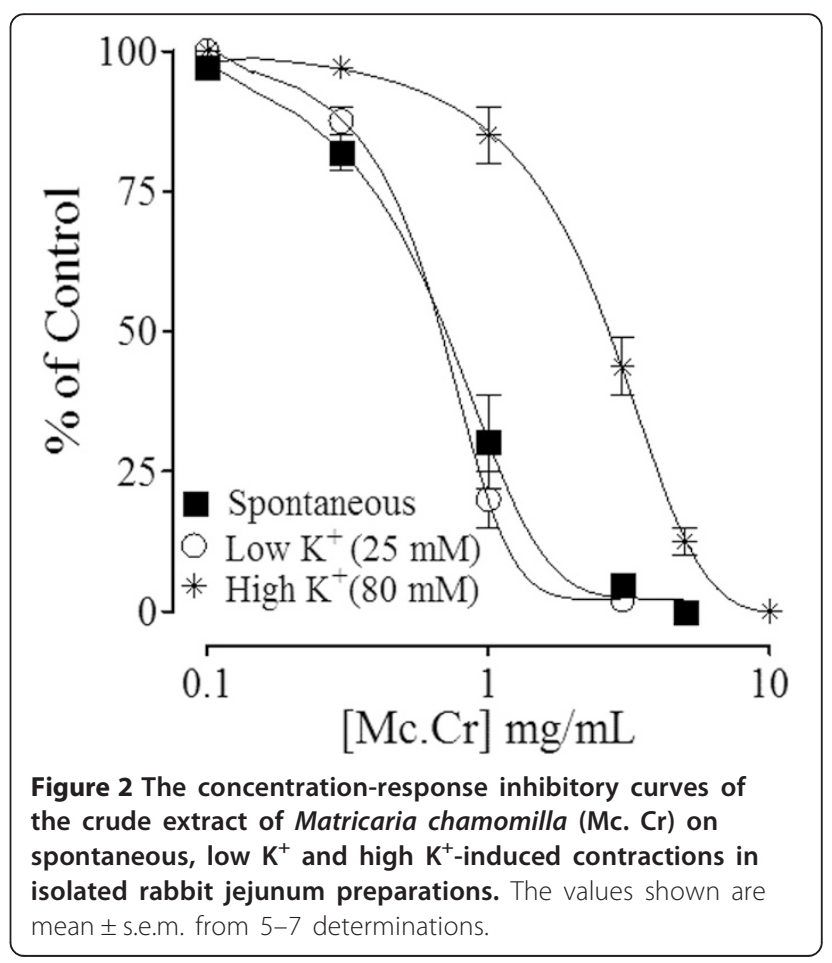



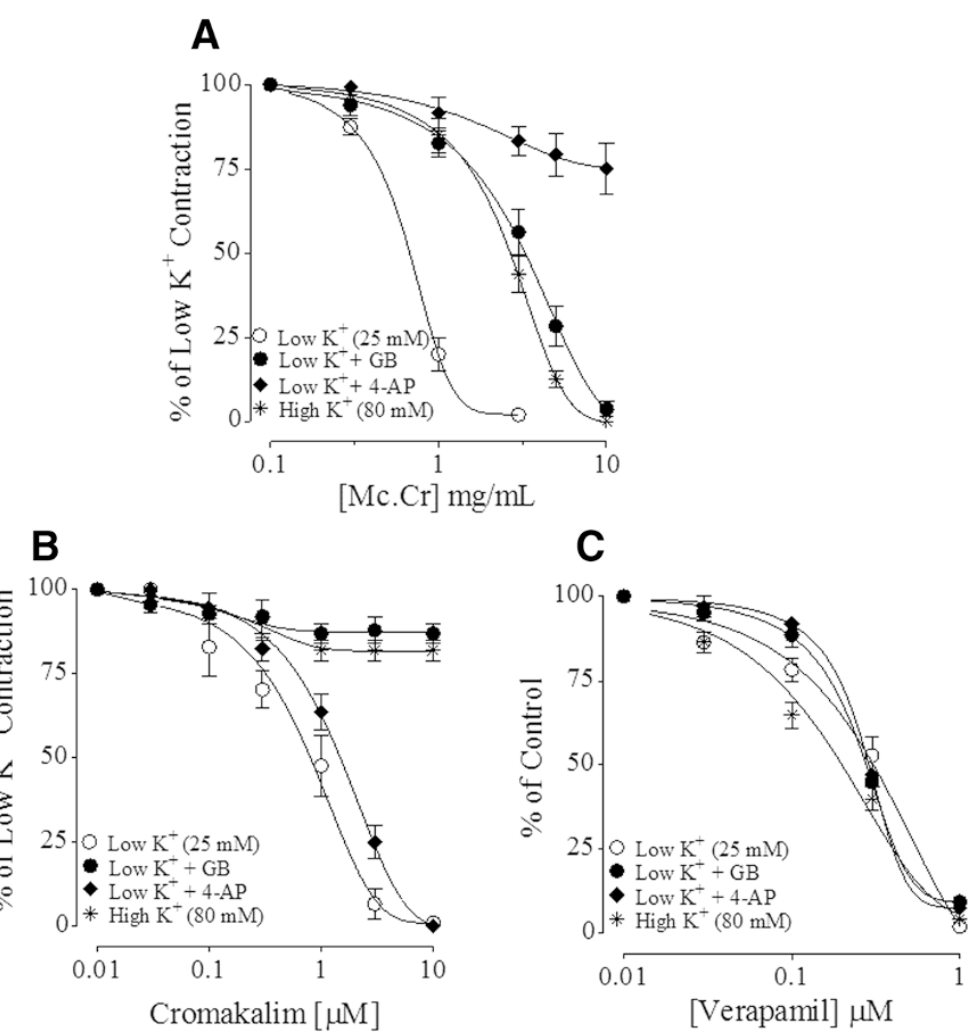

Figure 3 Antispasmodic effect of Matricaria chamomilla against low $\mathrm{K}^{+}(25 \mathrm{mM})$ contractions. Concentration-response inhibitory curves showing comparison of (A) the crude extract of Matricaria chamomilla (Mc. $\mathrm{Cr}$ ), (B) cromakalim and (C) verapamil in the absence and presences of $10 \mu \mathrm{M}$ glibenclamide (GB) or $1 \mathrm{mM}$ 4-aminopyridine (4-AP) against low $\mathrm{K}^{+}(25 \mathrm{mM})$-induced contractions in isolated rabbit jejunum preparations. The values shown are mean \pm s.e.m. from 4-6 determinations.

$100 \%$ (without GB) at the highest tested concentration $(10 \mu \mathrm{M})$. However, there was no significant change in the relaxant effect of cromakalim $[(1.10 \mu \mathrm{M}(0.68-1.89, \mathrm{n}=5)$ vs. $0.92 \mu \mathrm{M}(0.56-1.34, \mathrm{n}=4)]$ when reproduced in the presence of 4-AP, as shown in Figure 3B. Verapamil caused relaxation of high $\mathrm{K}^{+}$and low $\mathrm{K}^{+}$-induced contractions at similar concentrations with respective $\mathrm{EC}_{50}$ values of $0.19 \mu \mathrm{M}(0.12-0.28, \mathrm{n}=6)$ and $0.27 \mu \mathrm{M}(0.20$ $0.37, \mathrm{n}=5$ ). However, the relaxant effect of verapamil on low $\mathrm{K}^{+}$-induced contractions was found insensitive to $\mathrm{GB}$ and 4-AP (Figure 3C).

The inhibitory effect of the plant extract was studied on high $\mathrm{K}^{+}$-induced contractions, to confirm if it exhibits $\mathrm{Ca}^{++}$channel blockade-like activity at high doses. Interestingly the plant extract caused a rightward shift in the concentration response curves (CRCs) of $\mathrm{Ca}^{++}$with the suppression of the maximum response at 1 and $3 \mathrm{mg} / \mathrm{ml}$, respectively (Figure 4A). A positive control, verapamil also produced a rightward shift in the CRCs of $\mathrm{Ca}^{++}$and showed marked attenuation in the maximum response of $\mathrm{Ca}^{++}$at applied concentrations of 0.03 and $0.1 \mu \mathrm{M}$ (Figure 4B). Cromakalim was devoid of any effect in the CRCs of $\mathrm{Ca}^{++}$(Figure 4C) as expected.

\section{Discussion}

To validate the medicinal use of the crude extract of Matricaria chamomilla in hyperactive gut disorders, like diarrhoea and abdominal colic $[1,6]$, this study was designed to determine the antidiarrhoeal, antisecretory and antispasmodic activities of the plant extract using the invivo and in-vitro assays. To study the insight into mechanisms isolated rabbit jejunum preparations were used.

In castor oil-induced diarrhoea and intestinal fluid accumulation models, Mc. Cr showed antidiarrhoeal and antisecretory activities at 150 and $300 \mathrm{mg} / \mathrm{kg}$, similar to the effects of cromakalim [38] and loperamide [39], which are known for their spasmolytic, antidiarrhoeal and antisecretory activities. Castor oil is known to cause increased intestinal fluid contents and promotes diarrhoea indirectly through the effect of its active constituent, ricinoleic acid formed by the hydrolysis of oil [40], which changes the electrolytes and water transport [41] and generates massive contractions in transverse and distal colon [42]. The observed antidiarrhoeal and antisecretory effects of the plant extract appear to be mediated partly through the involvement of potassium channels activation which was evident by partial attenuation of these effects when 
A

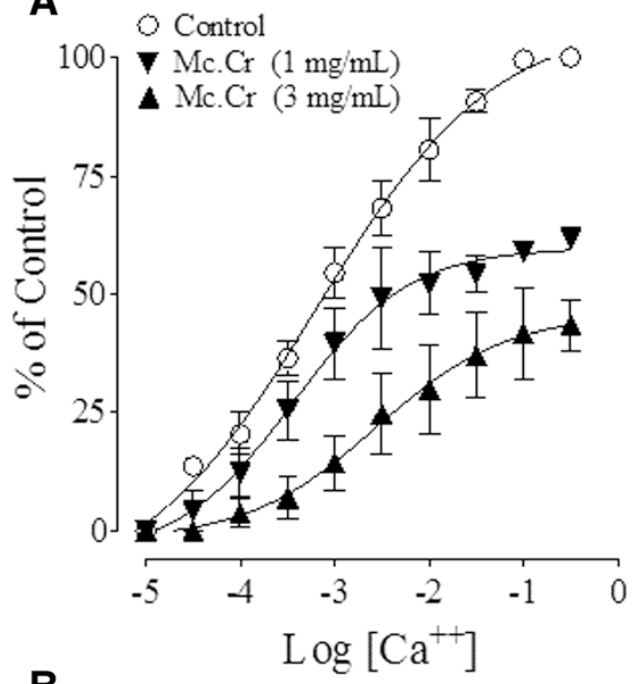

B

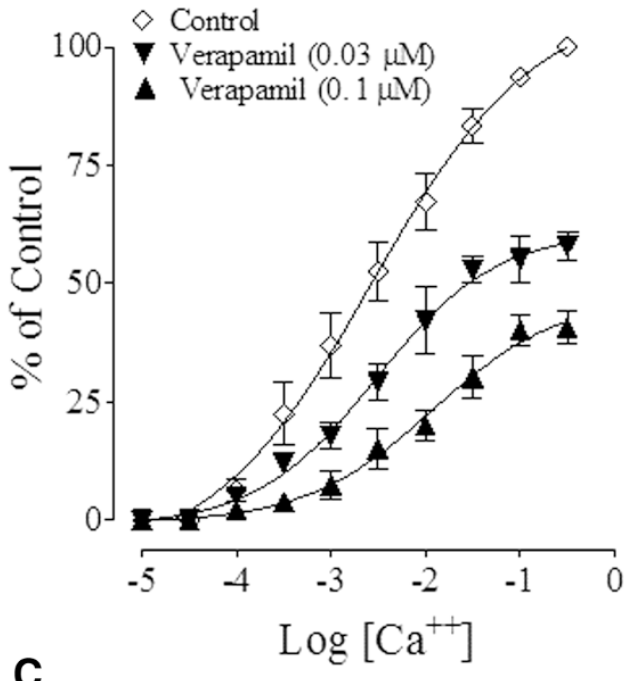

C $\diamond$ Control

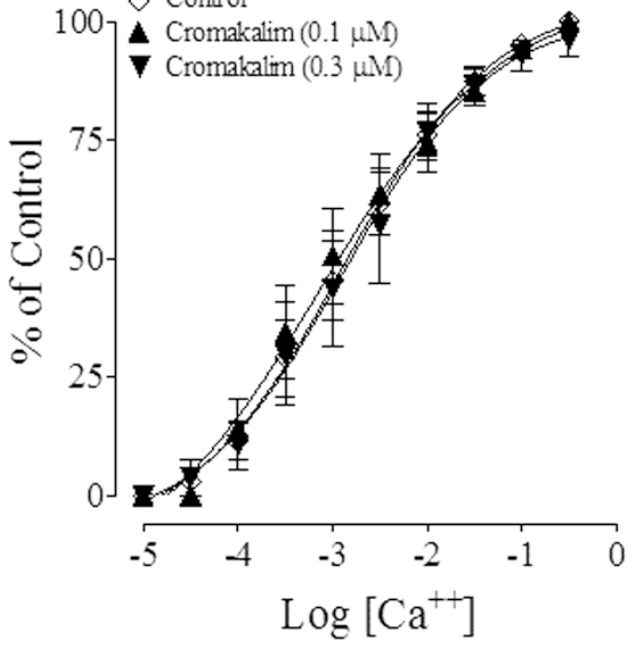

Figure $4 \mathrm{Ca}^{++}$antagonist effect of Matricaria chamomilla against $\mathrm{CaCl}_{2}$ contractions. The concentration-response curves of $\mathrm{Ca}^{++}$constructed in the absence and presence of increasing concentration of (A) The crude extract of Matricaria chamomilla (Mc. Cr), (B) verapamil and (C) cromakalim in isolated rabbit jejunum preparations. The values shown are mean \pm s.e.m. from 4-5 determinations.

reproduced in mice pretreated with glibenclamide (GB), an ATP-dependent $\mathrm{K}^{+}$channel blocker [34] or 4aminopyridine (4-AP), a voltage-dependent $\mathrm{K}^{+}$channel blocker [35], thus, indicating the presence of gut inhibitory constituents in Mc. Cr which might me mediating its observed antidiarrhoeal and antisecretory effects.

The role of multiple types of physiological mediators, such as, acetylcholine, histamine, substance-P, cholecystokinins, prostaglandins and 5-hydroxytryptamine [43] and some ion channels like, $\mathrm{K}^{+}$or $\mathrm{Ca}^{++}$, is well established in regulatory function of gastrointestinal system. Further, it has also been documented that most of the spasmolytic agents have therapeutic potential in diarrhoea by causing relaxation of the smooth muscle of the gut, in turn retain luminal fluid in the bowl [38,44].

It has been observed that most of the plant and plantbased test materials exhibit inhibitory effect through $\mathrm{K}^{+}$ channel activation or $\mathrm{Ca}^{++}$channel blockade like mechanisms $[30-33,45,46]$. The use of low $\mathrm{K}^{+}(25 \mathrm{mM})$ and high $\mathrm{K}^{+}(80 \mathrm{mM})$-induced depolarization in the tissues is usually carried out to distinguish $\mathrm{K}^{+}$channel opening and $\mathrm{Ca}^{++}$channel blocking like activities [32,33]. On the basis of presence of $\mathrm{K}^{+}$channels and voltage dependent $\mathrm{Ca}^{++}$ channels in intestinal smooth muscles and epithelial cells [46], $\mathrm{K}^{+}$channel openers (increase in $\mathrm{K}^{+}$efflux) and $\mathrm{Ca}^{++}$ antagonists (inhibition of $\mathrm{Ca}^{++}$entry) cause smooth muscle relaxation by decreasing intracellular free $\mathrm{Ca}^{++}$, through respective mechanisms of membrane hyperpolarization [38,44].

To assess whether the inhibitory effect of Mc. Cr was also mediated via similar mechanisms, it was tested on low and high $\mathrm{K}^{+}$-induced contractions in isolated rabbit jejunum, where it caused complete relaxation of low and high $\mathrm{K}^{+}$-induced contractions, being more potent against low $\mathrm{K}^{+}$. Cromakalim, a known ATP-dependent $\mathrm{K}^{+}$-channel opener [38], inhibited only low $\mathrm{K}^{+}$-induced contractions, while verapamil, a known $\mathrm{Ca}^{++}$antagonist [44], was found equipotent against both low and high $\mathrm{K}^{+}$-induced contractions. These data show that the presence of spasmolytic constituents in Matricaria chamomilla, is likely to be responsible for its observed antidiarrhoeal and antisecretory activities in mice, mediating their effect primarily through $\mathrm{K}^{+}$channel opening (KCO) along with weak $\mathrm{Ca}^{++}$channel blockade (CCB) component.

To know the nature of $\mathrm{K}^{+}$channels involved in $\mathrm{KCO}$ activity of Mc. Cr, the inhibitory CRCs of plant extract 
against low $\mathrm{K}^{+}$were constructed in the absence and presence of GB or 4-AP. Interestingly, in line with in vivo findings in mice, the inhibitory effect of Mc. Cr was potently inhibited in the presence 4-AP compared to GB. This indicates that the $\mathrm{KCO}$ activity of plant extract predominantly involves voltage-dependent $\mathrm{K}^{+}$channels along with ATP-sensitive $\mathrm{K}^{+}$channels, which are abundantly present in intestinal smooth muscles and are also known for their inhibitory influence in hypermotile gut [47].

The concentration of $\mathrm{K}^{+}>30 \mathrm{mM}$, regarded as high $\mathrm{K}^{+}$, is known to cause smooth muscle contractions through opening of voltage-dependent $\mathrm{Ca}^{++}$channels [36]. Thus, a substance that inhibits high $\mathrm{K}^{+}$-provoked contractions is considered a blocker of $\mathrm{Ca}^{++}$influx [48]. The $\mathrm{Ca}^{++}$antagonist effect was confirmed when Mc. Cr, at slightly higher concentrations, shifted the CRCs of $\mathrm{Ca}^{++}$to the right with suppression of the maximum effect, a typical characteristic of $\mathrm{Ca}^{++}$antagonists [37], which are known for their antispasmodic, antisecretory and antidiarrhoeal activities $[43,44]$. These findings attest the presence of CCBlike spasmolytic continents in Matricaria chamomilla in addition to its primary effect as $\mathrm{K}^{+}$channel opener. This study are not only provides an evidence to the medicinal use of Matricaria chemomilla in diarrhoea but also highlights the potential of this popular medicinal plant for the development of newer therapeutic options to treat hyperactive gut disorders, such as gut spasms and diarrhoea.

\section{Conclusions}

These findings indicate that Matricaria chamomilla possesses antidiarrhoeal, antisecretory and antispasmodic activities mediated predominantly through $\mathrm{K}^{+}$channels activation along with weak $\mathrm{Ca}^{++}$channel antagonist like pathways, thus, providing an evidence to the medicinal use of Matricaria chamomilla in abdominal colic and diarrhoea.

\section{Abbreviations}

Mc. Cr: Crude extract of Matricaria chamomilla; Low $\mathrm{K}^{+}: \mathrm{K}^{+}(25 \mathrm{mM})$; High $\mathrm{K}^{+}: \mathrm{K}^{+}$(80 mM); GB: Glibenclamide; 4-AP: 4-aminopyridine; $\mathrm{EC}_{50}$ : Effective concentration producing 50\% effect; $\mathrm{Cl}$ : Confidence interval; ACh: Acetylcholine; CRCs: Concentration-response curves; p.o.: Per oral; i.p: Intraperitoneally; $\mathrm{KCO}: \mathrm{K}^{+}$channel opening; $\mathrm{CCB}$ : $\mathrm{Ca}^{++}$ channel blockade.

\section{Competing interests}

The authors declare that they have no competing interests.

\section{Authors' contributions}

MHM designed the project, supervised the study and drafted final manuscript. SM and UAK carried out literature search, experimental work and data acquisition. AHG contributed in study design and review of the manuscript. MA identified and procured the plant material and reviewed the manuscript for publication. All authors read and approved the final manuscript for publication.

\section{Authors' information}

MHM is an Assistant Professor at Natural Product Research Division,Department of Biological and Biomedical Sciences, Faculty of Health Sciences, Medical College, The Aga Khan University, Stadium Road, P.O. Box 3500, Karachi 74800, Pakistan. SM and UAK are undergraduate medical students at Medical College,
The Aga Khan University, Stadium Road, P.O. Box 3500, Karachi 74800, Pakistan. AHG is a Professor of Pharmacology at Natural Product Research Unit, Department of Biological and Biomedical Sciences, The Aga Khan University Medical College, Karachi-74800, Pakistan. MA is Professor at Department of Botany, University of Balochistan, Quetta.

\section{Acknowledgement}

The study was carried out during Research Module of the Undergraduate Students. The financial support was provided to Dr. Malik Hassan Mehmood from the Department of Biological and Biomedical Sciences, The Aga Khan University.

\section{Author details}

${ }^{1}$ Natural Product Research Division, Department of Biological and Biomedical Sciences, Faculty of Health Sciences, Medical College, The Aga Khan University, Stadium Road, P.O. Box 3500, Karachi 74800, Pakistan.

${ }^{2}$ Department of Botany, University of Balochistan, Quetta, Pakistan.

Received: 29 April 2014 Accepted: 28 February 2015

Published online: 24 March 2015

\section{References}

1. Grieve M, Leyel CF. The medicinal, culinary, cosmetic and economic properties, cultivation and folklore of herbs, grasses, fungi, shrubs and trees with all their modern scientific uses. In: A modern herbal. Tiger books International, Mackays of Chatham, PLC, Chatham, Kent; 1994, pp. 961-962.

2. Ahmad S, Koukab S, Razzaq N, Islam M, Rose A, Aslam M. Cultivation of Matricaria recutita $\mathrm{L}$. in highlands of Balochistan, Pakistan. Pakistan J Agric Res. 2011;24:35-41.

3. Ali Sl, Qaiser M. Flora of Pakistan (No. 207) Asteraceae (1) Anthemideae by Abdul Ghafoor. Botany Department University Karachi; 2002, 172.

4. Duke JA, Bogenschutz-Godwin MJ, Du Celliar J, Duke PAK. Plantago ovata F. In: Hand book of medicinal herbs. 2nd ed. Boca Raton: CRC Press; 2002. p. 174-5.

5. Singh O, Khanam Z, Misra N, Srivastava MK. Chamomile (Matricaria chamomilla L.): an overview. Pharmacogn Rev. 2011;5:82-95.

6. Nadkarni KM: 1986. Indian Materia Medica. $3^{\text {rd }}$ revised and enlarged ed., Popular Prakashan, Bombay; 1986, 772.

7. de la Motte S, Bose-O'Reilly S, Heinisch M, Harrison F. Double-blind comparison of an apple pectin-chamomile extract preparation with placebo in children with diarrhoea. Arzneimittelforschung. 1997;47:1247-9.

8. Weizman Z, Alkrinawi S, Goldfarb D, Bitran C. Efficacy of herbal tea preparation in infantile colic. J Pediatr. 1993;122:650-2.

9. World Health Organization. WHO monographs on selected medicinal plants, vol. 1. Geneva: World Health Organization; 1999.

10. Baquar SR. Matricaria chamomilla L. In: Medicinal and poisonous plants of Pakistan. Karachi, Pakistan: Printas Karachi; 1989. p. 278.

11. Issac O. Recent progress in chamomile research- medicines of plant origin in modern therapy. 1st ed. Czecho-Slovakia: Prague press; 1989.

12. Das M, Mallavarapu GR, Kumar S. Chamomile (Chamomilla recutita): economic botany, biology, chemistry, domestication and cultivation. J Med Aromat Plant Sci. 1998;20:1074-109.

13. Kumar S, Das M, Singh A, Ram G, Mallavarapu GR, Ramesh S. J Med Aromat Plant Sci. 2001;23:617-23.

14. Lawrence BM. Progress in essential oils. Perfume Flavorist. 1987;12:35-52

15. Mann C, Staba EJ. The chemistry, pharmacology and commercial formulations of chamomile. In: Craker LE, Simon JE, editors. Herbs, spices and medicinal plants- recent advances in botany, horticulture and pharmacology. Phoenix: Oryx Press; 1986. p. 235-80.

16. Schilcher H, Imming P, Goeters S. Active chemical constituents of Matricaria chamomilla L. syn. Chamomilla recutita L. Rauschert. In: Franke R, Schilcher H, editors. Chamomile-industrial profiles. Boca Raton: CRC Press; 2005. p. 55-76.

17. Kunde $\mathrm{R}$, Isaac $\mathrm{O}$. On the flavones of chamomile (Matricaria chamomilla L.) and a new acetylated apigenin-7-glucoside. Planta Med. 1980;37:124-30.

18. Petrulová-Poracká V, Repčák M, Vilková M, Imrich J. Coumarins of Matricaria chamomilla L.: aglycones and glycosides. Food Chem. 2013;141:54-9.

19. European Pharmacopoeia. $5^{\text {th }}$ ed. Strasbourg, France: European directorate for the quality of medicines of the council of Europe; 1996, 1976-1977.

20. Mazokopakis EE, Vrentzos GE, Papadakis JA, Babalis DE, Ganotakis ES. Wild chamomile (Matricaria recutita L) mouthwashes in methotrexate-induced oral mucositis. Phytomedicine. 2005;12:25-7. 
21. Maschi O, Cero ED, Galli GV, Caruso D, Bosisio E, Dell' Agli M. Inhibition of human cAMP-phosphodiesterase as a mechanism of the spasmolytic effect of Matricaria recutita L. J Agric Food Chem. 2008;56:5015-20.

22. Achterrath-Tuckermann U, Kunde R, Flaskamp E. Pharmacological investigations with compounds of chamomile. V. Investigations on the spasmolytic effect of compounds of chamomile and Kamillosan on the isolated guinea pig ileum. Planta Med. 1980;39:38-50.

23. Shikov AN, Pozharitskaya ON, Makarov VG, Kvetnaya AS. Antibacterial activity of Chamomilla recutita oil extract against Helicobacter pylori. Phytother Res. 2008:22:252-3.

24. Kato A, Minoshima Y, Yamamoto J, Adachi I, Watson AA, Nash RJ. Protective effects of dietary chamomile tea on diabetic complications. J Agric Food Chem. 2008:56:8206-11.

25. Cemek M, Kaga S, Simsek N, Buyukokuroglu ME, Konuk M. Antihyperglycemic and antioxidative potential of Matricaria chamomilla L. in streptozotocin-induced diabetic rats. J Nat Med. 2008;62:284-93.

26. Asadi-Shahmirzadi A, Mozaffari S, Sanei Y, Baeeri M, Hajiaghaee R, Monsef-Esfahani HR, et al. Benefit of Aloe vera and Matricaria recutita mixture in rat irritable bowel syndrome: Combination of antioxidant and spasmolytic effects. Chin J Integr Med. 2012; Dec 21. [Epub ahead of print]

27. Williamson EM, Okpako DT, Evans FJ. Pharmacological methods in phytotherapy research. Chichester: John Wiley\& Sons; 1998. p. 15-23.

28. National Research Council. Guide for the care and use of laboratory animals. Washington: National Academy Press; 1996. p. 1-7.

29. Umer S, Tekewe A, Kebede N. Antidiarrhoeal and antimicrobial activity of Calpurnia aurea leaf extract. BMC Complement Altern Med. 2013;13:21.

30. Mehmood MH, Aziz N, Ghayur MN, Gilani AH. Pharmacological basis for the medicinal use of Psyllium husk (Ispaghula) in constipation and diarrhoea. Dig Dis Sci. 2010;56:1460-71.

31. Mehmood MH, Gilani AH. Pharmacological basis for the medicinal use of black pepper and piperine in gastrointestinal disorders. J Med Food. 2010;13:1086-96.

32. Gilani AH, Mehmood MH, Janbaz KH, Khan A, Saeed SA Ethnopharmacological studies on antispasmodic and antiplatelet activities of Ficus carica. J Ethnopharmacol. 2008;119:1-5.

33. Mehmood MH, Siddiqi HS, Gilani AH. The antidiarrhoeal and spasmolytic activities of Phyllanthus emblica Linn. are mediated through dual blockade of muscarinic receptors and Calcium channels. J Ethnopharmacol. 2011;133:856-65.

34. Frank H, Puschmann A, Schusdziarra V, Allescher HD. Functional evidence for a glibenclamide-sensitive $\mathrm{K}^{+}$channel in rat ileal smooth muscle. Eur J Pharmacol. 1994;271:379-86.

35. Satake N, Shibata M, Shibata S. The inhibitory effects of iberiotoxin and 4-aminopyridine on the relaxation induced by beta ${ }_{1}$-and beta $_{2}$-adrenoceptor activation in rat aortic rings. Br J Pharmacol. 1996;119:505-10.

36. Farre AJ, Colombo M, Fort M, Gutierrez B. Differential effects of various $\mathrm{Ca}^{++}$ antagonists. Gen Pharmacol. 1991;22:177-81.

37. Van-Rossum JM. Cumulative concentration-response curves. II. Techniques for the making of concentration-response curves in isolated organs and the evaluation of drug parameters. Arch Int Pharmacodyn Ther. 1963;143:299-330.

38. Poggioli R, Benelli A, Arletti R, Cavazzuti E, Bertolini A. K channel openers delay intestinal transit and have antidiarrhoeal activity. Eur J Pharmacol. 1995;287:207-9.

39. Reynolds IJ, Gould RJ, Snyder SH. Loperamide: blockade of calcium channels as a mechanism for antidiarrhoeal effects. J Pharmacol Exp Ther. 1984;231:628-32

40. Iwao I, Terada Y. On the mechanism of diarrhoea due to castor oil. Japanese J Pharmacol. 1962;12:137-45.

41. Gaginella TS, Phillips SF. Ricinoleic acid: current view of ancient oi. Dig DisSc. 1975;20:1171-7.

42. Croci T, Landi M, Elmonds X, Le-Fur G, Maffrand JP, Manara L. Role of tachykinins in castor oil induced diarrhoea in rats. Br J Pharmacol. 1997;121:375-80.

43. Pasricha PJ. Goodman's and Gilman's: treatment of disorders of bowel motility and water flux- the pharmacological basis of therapeutics. 11th ed. New York: McGraw-Hill; 2006. p. 983-1008

44. Lee CW, Sarna SK, Singaram C, Casper MA. Ca ${ }^{++}$channel blockade by verapamil inhibits GMCs and diarrhoea during small intestinal inflammation. Am J Physiol. 1997;273:785-94.
45. Khan A, Najeeb-ur- Rehman, Al-Taweel AM, Perveen S, Fawzy GA, Gilani AH. Studies on prokinetic, laxative, antidiarrhoeal and gut modulatory activities of the aqueous-methanol extract of Celtis africana and underlying mechanisms. Int J Pharmacol. 2012;8:701-7.

46. Khan A, Rehman NU, AlKharfy KM, Gilani AH. Antidiarrhoeal and antispasmodic activities of Salvia officinalis are mediated through activation of $\mathrm{K}^{+}$channels. Bangladesh J Pharmacol. 2011;6:110-6.

47. Vogalis F. Potassium channels in gastrointestinal smooth muscle. J Auton Pharmacol. 2000;20:207-19.

48. Chaudhary MA, Imran I, Bashir S, Mehmood MH, Rehman NU, Gilani AH. Evaluation of gut modulatory and bronchodilator activities of Amaranthus spinosus Linn. BMC Complement Altern Med. 2012;12:166.

\section{Submit your next manuscript to BioMed Central and take full advantage of:}

- Convenient online submission

- Thorough peer review

- No space constraints or color figure charges

- Immediate publication on acceptance

- Inclusion in PubMed, CAS, Scopus and Google Scholar

- Research which is freely available for redistribution 